Kalashova Kh.Kh., Aliyev B.A.•

DOI: 10.25108/2304-1730-1749.iolr.2018.57.220-242

\title{
State secrets and conservation authorities
}

\begin{abstract}
The General Provisions of the Decision-Making Procedure for the Prevention of Illegal Dissemination of Information Constituting State Secrets states that the decision on the unlawful dissemination of information constituting state secrets is confidential, whereby information disseminated and disseminated by the competent authority, is approved by the state authority, confirming the referenced list.
\end{abstract}

State power bodies authorized to issue orders on state secrets and information given to their decree are defined by the "List of State Secrets" approved by Decree 248 of the President of the Republic of Azerbaijan dated June 3,2005 . The decision on the illegal dissemination of information constituting state secrets is made by evaluating the materials of the official investigation of this fact.

Preparation and submission of materials on the results of official investigation of the facts of illegal dissemination of information constituting state secrets According to the Decree of the Cabinet of Ministers of the Republic of Azerbaijan dated 15 March 2005 "On the illegal dissemination of state secrets and the Rules of Preparation and Approval of Expert Opinion".

The List of Information Concerning State Secret (hereinafter - the List) was compiled in accordance with the Law of the Republic of Azerbaijan "On State Secrets". The list includes information that is related to the State's military,

\footnotetext{
- Kalashova Khayala Khaqani qizi - Senior Research Fellow of " The legal provision of state security" department of the İnstitute of Law and Human Rights (Azerbaijan). Email: xayala_kalashova@yahoo.com

Aliyev Bakhtiyar Abdurahman - PhD in Law, Associate Professor, Head of department "Legal provision of state security" of the İnstitute of Law and Human Rights of the National Academy of Sciences of the Republic of Azerbaijan (Azerbaijan). Email:antiterror-baku@ mail.ru
} 
foreign-political, economic, intelligence, counter-intelligence and operationalsearch activity, protected by the state and spreading information that may damage the security of the Republic of Azerbaijan, as well as state authority authorizing such information authorities are identified.

The List of State Secrets uses a number of concepts and acronyms:

- 'modified facilities' - Military and special facilities, military units, enterprises, institutions and organizations that have established additional security measures for their activities;

- 'military facilities' - combat positions of the troops, control points, landfills, communication nodes, radio technical systems, bases, warehouses and other military installations;

- 'special facilities' - the state and the Armed Forces of the Republic of Azerbaijan during the war, as well as other objects providing the activity of state power bodies of the Azerbaijan Republic;

- 'enterprises and organizations' - legal entities created in accordance with the legislation of the Republic of Azerbaijan, as well as their affiliates and representations irrespective of their type of ownership;

- 'Armies'- Armed Forces of the Republic of Azerbaijan and other armed units created in accordance with the legislation of the Republic of Azerbaijan;

- 'weapon' means designed to destroy enemy forces, equipment, facilities and other objects, their components and accessories;

- 'military equipment' means the technical means for the military, technical and archival maintenance of the troops, as well as the equipment and apparatus and their components and accessories for controlling these means;

- 'objects of state protection' - persons to be protected by the state;

- 'protected objects' - buildings, structures and structures located in the state power bodies, areas and structures that are adjacent to those buildings, structures and installations, to protect the security of state protection objects, as well as 
buildings under the disposal of the Special State Protection Service of the Azerbaijan Republic, buildings, installations, adjacent areas and aqueducts.

Keywords: state secrets; military equipment; special objects; list; counterintelligence; state power bodies.

The decision on the unlawful dissemination of information constituting state secrets is made by evaluating the material of the official investigation of this fact. Preparation and submission of materials on the results of official investigation of the facts of illegal dissemination of information constituting state secrets According to the Decree of the Cabinet of Ministers of the Republic of Azerbaijan dated March 15, 2005, "On the illegal dissemination of information constituting state secrets and Expert Report Preparation and Approval" [4, p.12].

The decision on the fact of the illegal dissemination of information is made by the expert commission and signed by the head of the state body authorized to dispatch disseminated information. The decision covers the following issues:

- sending of materials on the official investigation of the facts of the illegal distribution of the information to the body conducting the investigation of such cases - the State Security Service of the Republic of Azerbaijan (hereinafter - the investigation body);

- assignments on improving the state secrets protection system;

- responsibility for guilty persons;

- making changes to the list of confidential information.

The materials on the official investigation of the fact of the illegal dissemination of information constituting state secrets shall be evaluated on the basis of an expert commission prepared by the expert commission on the list of confidential information to be disclosed on the state authority authorized to issue such information. 
The involvement of an expert of an outsourced organization in the expert commission is carried out with the consent of the expert commission and the head of that organization. The expert involved in the expert commission should be the person who is not interested in the investigation and has the appropriate form of working with the state secret. The time of the meeting of the commission of experts and the persons to be involved in the expert commission shall be determined by the chairman of the commission. Experts determined by the leadership of the State Security Service may be directly involved in the work of the expert commission [5, p.6].

The meeting of the expert commission should be held in a room where the state secret is exhausted by technical channels. In the organization of the meeting of the expert commission the section on protection of the state secrets of the state power body is involved and is responsible for the protection of the state secrets during the session.

Evaluation of the material investigation of the fact of the information dissemination includes a number of cases:

- assessing the objectivity of the expert opinion on the degree of confidentiality and the degree of confidentiality, as well as the damage caused by the inquiry commission;

- evaluation of the adequacy of the measures taken to improve the effectiveness of the state secrets protection system in the organization where the facts of information dissemination are taking place.

When evaluating the objectivity of an expert opinion on the extent of confidentiality of the information generated by the State Secret, the following shall be considered:

- whether the principles of the State Secrets of the Republic of Azerbaijan were complied with in the confidentiality of information; 
- whether the information bearer has the requisites established by the Law on State Secrets, including the date or condition of disclosure of the confidentiality of the information or the event that could have caused it;

- whether the conformity of the confidentiality of the information and the degree of confidentiality previously disclosed has been verified within the period specified by the Law on State Secrets.

Damage caused as a result of illegal distribution of information is determined based on the normative-methodological document prepared in accordance with "the Rules of State Data Secreting" approved by the Decree of the President of the Republic of Azerbaijan dated June 3, 2005 No. 249.

If the expert commission does not agree with the expert opinion on the extent of the confidentiality of the disseminated information and the degree of confidentiality, or the investigation commission's disagreement, the expert commission shall review the matter. In this case, the expert commission shall carry out the preparation of an expert opinion on the public secret and dissemination of confidential information, as well as the determination of the damage.

All issues that arise during consideration and resolution of cases relating to the assessment of materials of the official investigation of the fact of the illegal dissemination of state secrets shall be resolved by a majority vote of the members of the expert commission. A member of the expert commission, who disagrees with the decision of the majority, may express his/her opinion in writing and the opinion is attached to the case [6, p. 2].

According to the Law on State Secrecy, the illegal dissemination of information results in damage to the interests of the Republic of Azerbaijan or the central executive power body, the case materials are considered by the Interstate Commission for the Protection of the State Secrets under the President of the Republic of Azerbaijan (hereinafter referred to as the Interdepartmental Commission). 
The decision on the unlawful dissemination of such information shall be taken into account in the light of the opinion of the Interagency Commission. I would like to note that the Interdepartmental Commission for the Protection of the State Secrets under the President of the Republic of Azerbaijan (hereinafter, InterAgency Commission) was established by Decree No. 539 of 17 January 1997 on the application of the Law of the Republic of Azerbaijan "On State Secrets" of the President of the Republic of Azerbaijan. Interdepartmental Commission is a collegial body that coordinates the activities of state authorities in the field of protection of state secrets for the development and implementation of state programs, normative legal acts and methodical documents ensuring the implementation of the legislation of the Republic of Azerbaijan on state secrets [7, p. 3].

The main objective of the Inter-Governmental Commission is to organize and ensure the protection of state secrets in accordance with the functions assigned to it by the legislation of the Republic of Azerbaijan.

The Interdepartmental Commission shall be guided by the Constitution of the Republic of Azerbaijan, the Law of the Republic of Azerbaijan on State Secrets, other laws of the Republic of Azerbaijan, decrees and orders of the President of the Republic of Azerbaijan, resolutions and orders of the Cabinet of Ministers of the Republic of Azerbaijan and this Statute [8, p. 5].

Interdepartmental Commission carries out the following functions to fulfill its mission:

- reviewing and reviewing the materials on the dissemination of information in cases where the illegal dissemination of information constituting state secrets resulted in damage to the security of the state as a whole on the Republic of Azerbaijan or the central executive authority;

- compiles and submits to the President of the Republic of Azerbaijan a list of information pertaining to state secrets, taking into account the list of information 
constituting the state secrets established by law and the state secrets and confidentiality of information, as well as the proposals of state authorities;

- develops state programs, normative-legal and methodological documents ensuring the implementation of the Law of the Republic of Azerbaijan "On State Secrets" or submits it to the relevant executive authorities for approval in the prescribed manner;

- submits to the President of the Republic of Azerbaijan and the Cabinet of Ministers of the Republic of Azerbaijan proposals on improvement and legal regulation of the state secrets protection system in the Azerbaijan Republic;

- adopts a decision on the procedure for disclosure of confidentiality of information carriers, when the fund-organizer is liquidated and there is no legal successor;

- examines inquiries of state authorities, enterprises, institutions, organizations and citizens on disclosure of confidentiality of information contained in state secrets in accordance with the Law of the Republic of Azerbaijan "On State Secrets";

- gives expert opinion to the Cabinet of Ministers of the Republic of Azerbaijan on the possibility of transferring state secrets to other states and international organizations;

- makes proposals to the President of the Republic of Azerbaijan on changing the procedure for issuing state secrets of officials and citizens in the conditions of military and extraordinary situation;

- in accordance with the instruction of the President of the Republic of Azerbaijan, considers draft international agreements of the Republic of Azerbaijan on joint protection and use of information constituting state secrets, prepares relevant proposals and expert opinions and cooperates with international organizations on these issues; 
- approves decisions on changing the confidential information lists valid in state power bodies, enterprises, institutions and organizations (when these decisions relate to changes in the list of information relating to state secrets), cease and protest those decisions;

- gives an opinion on the extension of confidentiality of information that constitutes the state secrets $[9$, p. 1].

It solves other issues arising from the Law of the Republic of Azerbaijan "On State Secrets" in accordance with the instructions of the President of the Republic of Azerbaijan. The Chairman of the Interdepartmental Commission is appointed and dismissed by the President of the Republic of Azerbaijan. The composition of the Inter-Governmental Commission is approved by the President of the Republic of Azerbaijan [10, p. 3].

The Secretariat of the Interdepartmental Commission (hereinafter referred to as the Secretariat) is established to ensure the functioning of the Inter-Agency Commission. The Secretariat's duties include:

- oversee the implementation of the decisions of the Inter-Agency Commission;

- coordinate the activities of state bodies in the implementation of legislation on state secrets;

- ensure that the President of the Republic of Azerbaijan and the Cabinet of Ministers of the Republic of Azerbaijan fulfill the tasks assigned to the InterAgency Commission;

- study the activities of state bodies in the implementation of legislation on state secrets to improve the state secrets protection system;

- cooperate with relevant organizations to study international experience in the field of state secrets protection;

- prepare proposals for the establishment of interdepartmental working and expert groups, as well as proposals for the involvement of individual organizations, 
including experts, for the purpose of addressing issues relating to the protection of state secrets and submits them to the Inter-Agency Commission for Review;

- carry out other functions entrusted to it by the Inter-Agency Commission for the functioning of the Inter-agency Commission [11, p. 2].

The duties of the Chairman of the Interdepartmental Commission include the following:

- may obtain the necessary information, documents and materials from the central executive authorities, local self-governance bodies, enterprises, institutions and organizations related to the activities of the Interagency Commission in accordance with the established procedure;

- establishes inter-agency expert groups to ensure the functioning of the InterAgency Commission;

- involves state and non-state enterprises, institutions and organizations and individual specialists on the basis of contract for expert, research and analytical work;

- approves and dismisses the Head of the Secretariat with the consent of the President of the Republic of Azerbaijan and accepts and dismisses the members of the Working Group on the presentation of the Working Group Leader.

Meetings of Interdepartmental Commission are held on the basis of a plan approved by the Chairman of the Interdepartmental Commission. If necessary, extraordinary meetings may be held on the initiative of the Chairman of the InterGovernmental Commission. Members of the Commission are important in the meetings of the Inter-Governmental Commission.

They cannot delegate their powers to other officials. If the Inter-Agency Commission member is unable to attend the meeting, his/her opinion on the issues discussed shall be in writing. The execution of the Inter-Governmental Commission's decisions under its authority is mandatory for state authorities, enterprises, institutions and organizations, and officials [12, p. 3]. 
Members of the Interdepartmental Commission have the same rights as decision-makers. If any member of the Inter-Governmental Commission disagrees with the decision taken, his special opinion will be added to the minutes of the meeting. Members of the Inter-Governmental Commission operate on a public basis. The material and technical supply of the Inter-Agency Commission and the Secretariat is funded from the state budget.

The decision on the fact of the illegal dissemination of information is made by the expert commission and signed by the head of the body of state authority authorized to dispatch disseminated information.

The decision covers the following issues:

- sending the materials on the service investigation of the fact of the illegal distribution of the information to the body conducting the investigation of such cases - to the State Security Service

- assignments to improve the state secrets protection system;

- responsibility for guilty persons within their authority as defined by law;

- changes to the information clause to be compiled.

It can be concluded that state secrets have become an essential part of the state's legal system as an integral part of social life. In the context of the formation of a democratic state, the scientific and legal value of the mystery system is a sharp tool of political influence, and is essential for many reasons [13, p. 119-131].

As you can see, state secrets, military secrets, service secrets are crucial to the security of the state and society and are protected by law. For this reason, such issues should only be known to strict categories and should be under constant supervision.

\section{References}

1. Azerbaijan Respublikasinin Konstitusiyasi ve huququn esaslari [The Constitution of the Republic of Azerbaijan and the Fundamentals of Law]. Baku, $2010,120 \mathrm{p}$. 
2. Approval of the Decree No. 162 of the Cabinet of Ministers of the Republic of Azerbaijan of October 17, 2002, "Procedure for empowering officials and citizens to work with state secrets". [Internet resource]. Available at: http:// www. e-qanun.az/framework/1216 (in Azerbaijani).

3. Jalilov Elman. Azerbaycan dovlet huququ [State law of Azerbaijan]. Baku, 2011, $326 \mathrm{p}$.

4. Dovlet sirrinin muhafizesi uzre normativ huquqi aktlar [Normative legal acts on the protection of state secrets]. Baku, 2005, $29 \mathrm{p}$.

5. "Dovlet sirri haqqinda" Azerbaycan Respublikasinin 7 sentyabr 2004-cu il Qanunu. [Law of 7 September 2004 of the Republic of Azerbaijan "On State Secrets"]. [Internet resource]. Available at: http://www.e-qanun.az/ framework 15526

6. http://din.nmr.az/2018/02/13/dovl\%C9\%99t-sirri-haqqinda-az\%C9\%99 azerbaycan-respublikasinin-qanunu/

7. http://www.e-imza.az/downloads/qanunlar/E-signature\%20law/Elektron\% 20imza\%20haqda\%20qanun.pdf

8. http://www.e-qanun.az/framework/9943

9. http://huquqiaktlar.gov.az/StatementDetails.aspx?statementId=33616

10. http: //mia.gov.az/index.php? / En / content / 2011

11. https://mod.gov.az/en/news/dovlet-sirrinin-muhafizesi-uzre-vacib-info 11970.html

12. http://www.mfa.gov.az/files/file/27.pdf

13. Vilic V. International and Serbian legal framework of the right to privacy in cyberspace. DOI: 10.12709/mest.06.06.01.13/ MEST Journal, vol. 6. No. 1 January 2018, pp. 119-131 